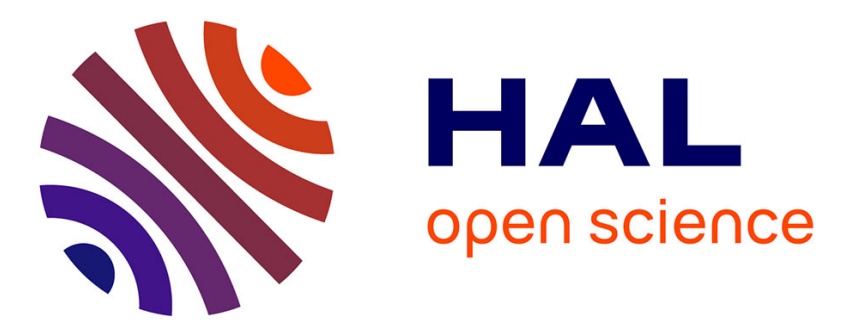

\title{
How can people be induced to willingly change their behavior? The path from persuasive communication to binding communication
}

Robert-Vincent Joule, Fabien Girandola, F. Bernard

\section{> To cite this version:}

Robert-Vincent Joule, Fabien Girandola, F. Bernard. How can people be induced to willingly change their behavior? The path from persuasive communication to binding communication. Social and Personality Psychology Compass, 2007, 1, pp.493-505. 10.1111/j.1751-9004.2007.00018.x hal-00585299

\section{HAL Id: hal-00585299 \\ https://u-bourgogne.hal.science/hal-00585299}

Submitted on 12 Apr 2011

HAL is a multi-disciplinary open access archive for the deposit and dissemination of scientific research documents, whether they are published or not. The documents may come from teaching and research institutions in France or abroad, or from public or private research centers.
L'archive ouverte pluridisciplinaire HAL, est destinée au dépôt et à la diffusion de documents scientifiques de niveau recherche, publiés ou non, émanant des établissements d'enseignement et de recherche français ou étrangers, des laboratoires publics ou privés. 
How Can People Be Induced to Willingly Change Their Behavior?

The Path from Persuasive Communication to Binding Communication

\title{
Robert-Vincent Joule,Fabien Girandolaand Françoise Bernard
}

\begin{abstract}
How can people be induced to willingly change their behavior? The present article has three main objectives. Its first purpose is to review some of the procedures pertaining to the 'free will' compliance paradigm. These procedures increase the likelihood that others will freely comply to one's requests (low-ball, teasing, foot-in-the door, touch, and 'you are free to' procedures). The second objective is to introduce a theory stemming from social psychology, namely, the theory of commitment. Finally, we wish to describe the binding communication

approach that can be situated at the intersection of research conducted in both the fields of communication, more specifically in the domain of persuasive communication, and the fields of commitment and free will compliance. A project carried out to encourage school children to behave in a more environmentally friendly way will be described to illustrate the approach.
\end{abstract}

\section{"Good Ideas" Don't Always Lead to "Proper Behavior"}

Quite obviously, protecting the environment, following the highway code, voting, using a condom, donating blood, helping a person in danger, or even just doing someone a small favor represent social behavior that should be promoted. But how can this be done?

A prevailing notion about human beings may lead to think that one merely needs to modify the ideas of others to make them behave in the desired way. Information and persuasion are, hence, widely used in the media (radio, television), as well as in the classroom or at home to encourage children and adults to adhere to the ideas required for social functioning. Most major communication campaigns follow this assumption. Manyprevention, education, and communication professionals suppose that as long as the information 'goes down well', and/or as long as the arguments are 'strong' enough, the proper behavior will automatically fall into place. Social psychologists have long been aware, however, of the limits of such an assumption. Informing and convincing are not enough, as 'good ideas' don't automatically lead to 'proper behavior'. Consider one of the most telling studies on this topic. Peterson, Kealey, Mann, Marek, and Sarason (2000) conducted an evaluation of the Hutchinson smoking prevention project. This project took place in Washington State and involved over 8,000 students divided into two groups: an experimental group and a control group. From the ages of 8 to 17 years, the students belonging to the experimental group (more than 4,000 ) took part in 65 prevention sessions while the students in the control group did not participate in these sessions. The program of these sessions was adapted to each age group and had been developed following the recommendations of the Centers for Disease Control and Prevention and those of a group of experts from the National Cancer Institute. The main purpose of these sessions was to inform the students in the experimental group of the negative effects of smoking and to convince them of the advantages of not taking up smoking. However, despite the efforts expended over a 10year period, the action had no effect; the smoking prevalence was not lower in the experimental group than in the control group! This is just one instance of the many studies that underscore the discrepancytheir behavior of their own free will. In the 1940s, Kurt Lewin blazed the trail for research into free will compliance. Decision-Making and Freezing Effect One may recall the poor outcome of the persuasive strategies tested by

Lewin (1947) to encourage American housewives to change their dietary patterns. To help prevent malnutrition, housewives were advised to cook inexpensive cut meat. It is fair to say that they went home fully informed and convinced by the arguments heard. But this did not keep them from behaving as if they had never attended the conference ( $3 \%$ cooked cut meat). However, during the presentation, when the housewives were asked for a show of hands to express their decision to serve offal, they were 10 times more likely to actually follow through with their decision $(32 \%$ cooked 
cut meat). This goes to show the importance of the decision. According to Kurt Lewin, there exists no direct link between the ideas in our mind and our effective behavior. It is therefore necessary to call on an intermediary link and this link is none other that the decision action itself. Taken as a whole, Lewin's famous action research shows the advantage of securing a decision from the people whose behavior one seeks to change, given that once a decision is made, people tend to stick to it (freezing effect). Some decisions are easy to obtain. One just needs to ask - a simple request - for a decision to be made. But those easily obtained decisions can sometimes lead quite far. They can change a bystander into an actor, or a coward into a hero, as shown by a study carried out in the mid-1970s (Moriarty, 1975). Stopping a thief The action takes place in a restaurant. Someone comes in carrying a briefcase and sits at a table, next to a person having dinner alone. A few minutes later, the man with the briefcase asks his neighbor for a light, thensteps out for a few minutes, leaving his briefcase unattended. A stranger enters the restaurant and tries to steal the briefcase. Only $12.5 \%$ of the people who had handed a light to the victim intervene to stop the thief. This percentage would be even lower if the bystander had had no prior contact with the victim. It wouldn't take much, however, for the bystander to react in a totally different way. Things would take another turn if the man with the briefcase had asked his neighbor for a different kind of small favor: for instance to keep an eye on his belongings. Indeed, in this situation, all bystanders, without exception, intervene to stop the thief. From a mere $12.5 \%$, the percentage soars to $100 \%$ ! People don't behave differently because they have different ideas. The patrons in the restaurant intervene - thus, carrying out the expected behavior (i.e. preventing theft) - because a stranger asked them to watchbetween one's ideas - namely, one's 'good ideas' - and one's actions. The Drug Abuse Resistance Education (DARE) program is another perfectexample of this gap. The DARE program, geared toward the preventionof drug use among teenagers, was set up in California and involved over9,000 students. Once again, although the program was effective in improvingthe students' overall knowledge of drugs and of their potential danger, its effectiveness in reducing drug use was poor (Dukes, Ullman, \& Stein,1996; Ennett, Tobler, Ringwalt, \&Flewelling, 1994).Of course, this does not mean that information and persuasion are useless. There is no question that, through time, information and persuasion serveto change knowledge, modify attitudes, and, most certainly, triggergenuine awareness. Information and persuasion are therefore necessary indeed, but not sufficient on their own (see, in particular, Albarracin,Gillette, Earl, Glasman, \&Durantini, 2005; Albarracin, Durantini, \& Earl,2006).So how then can behavior be changed? Social psychologists have beentrying to answer this question for the past 60 years, and there is now awealth of reliable scientific knowledge on this topic. We have suggestedthat the research carried out in this particular domain could be brought back to a single basic paradigm: free will compliance (cf. Joule \&Beauvois,1998, 2002). From a practical point of view, this paradigm may be definedas the study of the procedures, or techniques, likely to lead others to modifytheir things. Social norms being what they are, bystanders can do nothing else but comply. Their values, convictions, attitudes, nature, or personality have no bearings here. It all depends on circumstances. Given other circumstances, they would behave differently, for example, if the stranger had asked for a light, all the more so, if the stranger hadn't spoken to them at all. The psychological process leading up to a change in behavior lies on a simple, easy to obtain decision to keep an eye on the briefcase - and on the ensuing freezing effect. It goes without saying that some decisions are more difficult to secure than others and must, therefore, be prepared. There are several types of procedures enabling to prepare the ground for decisions likely to lead people to comply freely to what is expected of them. We have suggested to group these procedures in a single paradigm called 'free will compliance' ( Joule\&Beauvois, 1998). In this article, we will discuss just a few of these procedures: low-ball, teasing, foot-in-the-door, touch, you are free to (see Cialdini, 2000; Guéguen, 2002a; Joule \&Beauvois, 2002; Girandola, 2003, for a summary).

\section{Free Will Compliance}

Low-ball procedure

Cialdini, Cacioppo, Basset, and Miller (1978) were the first to describe the low-ball principle. A subject is led to make a decision, either by not being informed of its disadvantages or by being misled 
by false advantages. Once the decision is made, more details are provided, including information on the disadvantages of the decision or changes to the original positive deal. Subjects may then reiterate their decision or change their minds. The priming phenomenon translates into a tendency of subjects to strive to remain consistent with their first decisions although they needn't do so. Cialdini and his team carried out an experiment where students were invited to take part in a research. The participants, however, were not told that the research was planned to start at 7 a.m.! The students were informed of this early hour plan only once they had agreed to participate. The confederate then inquired to whether or not the students still agreed to take part in the research. The outcome is clear:

compared to the control group that were given all the information up front, the low-ball procedure doubles the likelihood that students will not change their minds and that they will indeed show up at 7 o'clock in the morning ( $24 \%$ versus 53\%, respectively). Both Moriarty's and Cialdini et al.'s researches show that individuals feel committed to a prior decision even when the conditions have changed. Decisions originally believed to be quite insignificant are maintained even when they suddenly turn out to be more costly than originally expected. The freezing effect as described by Lewin is not linked to the 'good reasons' that may have led participants to make a particular decision. If suchwere the case, people would reconsider their decision upon learning that their 'good reasons' are no longer applicable. But they tend not to reconsider precisely because the freezing effect is linked to the decision action per se rather than to the reasons for which a decision was made in the first place. The priming phenomenon provides a perfect illustration of this.

\section{The teasing procedure}

The teasing procedure ( Joule, Gouilloux, \& Weber, 1989) is quite similar to the low-ball procedure although its principle differs. People are encouraged to make a decision entailing positive consequences for them but that can only materialize ('teasing' request) after a less enticing decision is taken (substitution request). In an experiment carried out by Joule et al. (1989), students had agreed to participate in an interesting psychology research: they were to watch a really good movie and, on top of that, they would receive remuneration. The students were then informed that the research was cancelled and were invited to participate in a much less interesting - even boring nonremunerated research (repetitive paperand- pencil exercises). Twice as many students agreed to participate in this new study compared to the control condition where no 'teasing' requestwas made. Teasing has certain similarities with priming yet differs in one major way: in priming, both decisions are linked to the same object (for instance in Cialdini et al.'s experiment, i.e. to participate in a given study) while in teasing the first and second decision concern two different objects (for example, in Joule et al.'s experiment, i.e. to be paid to watch a good movie or to write repetitive exercises in a new nonremuneratedresearch). Teasing leads us to the foot-in-the-door procedure that also involves two decisions geared toward two different objects.

\section{The foot-in-the-door procedure}

The foot-in-the-door technique, first coined by Freedman and Fraser (1966), is unquestionably the oldest free will compliance procedure and one that has generated the most research (for a review, see, in particular, Burger, 1999). It should be mentioned that this procedure can be observed on a daily basis. Its principle is well known: a small request (preparatory action) is made prior to a more substantial one (expected behavior). In one of their most famous experiments, Freedman and Fraser began by asking housewives to answer a few innocuous questions over the phone about their consumption patterns (preparatory action). A few days later, the housewives received a phone request aimed at triggering the expected behavior. They were asked to agree to a 2-hour interview concerning household consumption. The interview was to be carried out in their home by a team of several men. Freedman and Fraser observed that such a costly request was twice as likely to be complied to when it waspreceded by a smaller request than in the control group where the housewives had not been contacted beforehand for a quick phone survey $(52 \%$

versus $22.2 \%$, respectively). 
In this foot-in-the-door experiment, an explicit request is aimed attriggering the expected behavior: 'Would you allow our team of surveyorsto interview you at home?' Such is not the case in other research, wherethe conditions likely to incite the person to spontaneously behave asexpected are set up without putting forth an explicit request. Insofar asthe expected behavior is not the object of a request per se, some researchersrefer to foot-in-the-door with implicit request.

\section{Foot-in-the-door with implicit request}

In a series of studies carried out in Aix-en-Provence, France (Joule, Py, \&Bernard, 2004), we were able to show just how easy it is, using the footin-the-door with implicit request technique, to make someone behave ina more honest way than he or she spontaneously would in normal circumstances. One such experiment took place in a deserted alley where apasserby was seen dropping a 10-dollar bill. A mere $20 \%$ of the eyewitnessescaught the passerby's attention while the other $80 \%$ let him moveon and grabbed the money!Yet, a carefully designed preparatory action could increase the likelihoodthat eyewitnesses would behave in a more honest way. The likelihood ofhonest behavior is multiplied by two (40\%) in situations where thebystanders are first led to do a small favor - for instance, give directions- to another passerby. And it is even higher (70\%) when the favor isslightly more costly, that is, to walk a distance of about 30 meters to helpsomeone find their way. Once again, if some people tend not to takemoney that doesn't belong to them, it has nothing to do with theirpersonality, values, or moral standards, but rather because they wereencouraged to carry out a preparatory action, that is, to do someone asmall favor. It thus seems that this first favor enables the person to makea connection between what she or he has done (namely, giving someonedirections or walking a few steps to help someone find their way) andwho he or she is (someone willing to help). And wouldn't such anobliging person tell a passerby that he or she has dropped money?

\section{Foot-in-the-door with labeling}

In another series of studies carried out in Aix-en-Provence (quoted by Joule\&Beauvois, 2002, 178180), we were able to show that the foot-in-thedoorprocedure could be even more efficient if the labeling techniquewas also used. One research took place on market day. A first confederatepretended to be a tourist and asked a shopper to help him read a city map(preparatory action). Once the favor had been secured and just beforeleaving the tourist confederate proceeded to label the shopper: 'I was so fortunate to come across someone as nice as you.' Later on, a secondconfederate in the crowd handed the shopper a banknote: 'Here, I thinkyou've lost this.' By doing so, the likelihood that an 'aixois' will turn downmoney that is not his or hers is eight times higher (64\%) than in the controlcondition (only $8 \%$ ) with only one confederate. This effect turned out tobe twice as high compared to a foot-in-the-door situation without labeling(30\%), where a first confederate warmly thanked the shopper for havinghelped him find his way on the map. The foot-inthe-door technique cantherefore be optimized by using the appropriate labeling, that is, one thatunderscores the personality trait corresponding to the expected behavior.

\section{The touch procedure}

The touch procedure was first identified in the 1970s and consists intouching a person's arm for 1 or 2 seconds to secure his or her compliance.In one of the first studies (Kleinke, 1973), a few coins were left ina phone booth. People leaving the phone booth were asked if they hadfound money in the booth. One time out of two, the confederate wouldnot just enquire about the coins but would also touch the person's armthus substantially improving the rate of return of the forgotten coinstwofold. The effectiveness of this procedure is well established. The effectof touch has been observed in different contexts and for various types ofbehavior. The University of Miami hosts the Touch Research Institute. Inthe medical field, hundreds of studies have been conducted proving thepositive effect of touch in securing compliance to a desired behavior.For example, patients touched by hospital staff were more likely to followmedical prescriptions, hospital patients experience less presurgery stresswhen a nurse has touched them, and finally patients are more likely to go 
back to a psychiatrist if he or she touched them during the first session.First observed in the USA typically a 'noncontact culture', the phenomenonremains effective in a 'contact culture' such as France. Guéguen(2002b) observed, for instance, that a person is twice as likely to give acoin to a stranger if he or she has touched his or her arm during therequest. In another study, Guéguen (2002c) observed that touching astudent's forearm during a corrective exercise multiplied by almost threethe likelihood that the student will volunteer to go to the board todemonstrate the exercise. This last research is in line with Americanresearch showing that a teacher can help students improve their schoolperformance by merely touching them (Steward \&Lupfer, 1987).

\section{The 'you are free to' procedure}

It was recently shown that explicitly calling on a person's feeling of freewill increases the likelihood that this person will behave according to one'sexpectations. The principle of this procedure is to end a request by specifying that the person is totally free to do (or not) what is requestedof him or her. This technique has enabled Guéguen and Pascual (2000)to multiply by four their chance of having people giving them money inthe street. They asked a stranger for money to take the bus, adding 'but you are free to accept or refuse' (10\% versus $47 \%$ with the 'you are freeto' procedure). Other studies (Guéguen, LeGouvello, Pascual, Morineau, \& Jacob, 2002) have shown that the fact of replacing the traditional 'clickhere' with 'you are free to click here' increases the number of hits on aWeb site.

The free will compliance procedures previously mentioned (priming,teasing, foot-in-the-door, touch, you are free to ... ) prove that it is in factquite easy to influence the behavior of others and to increase the likelihoodthat people will freely comply to what is expected of them. Theadvantage of these techniques is that they are more effective than othermore authoritarian procedures that are likely to be ineffective or inappropriate. Of course, it is out of the question that housewives be forced toagree to having a team of surveyors spend 2 hour in their homes. Likewise,we are not aiming at compelling a passerby to give us money to takethe bus. When we choose to talk about compliance insofar as peoplewould have spontaneously behaved differently - we are actually referringto a different type of compliance, that is, free will compliance.

\section{The Theory of Commitment}

In our opinion, the theory of commitment provides the best theoreticalinterpretation of free will compliance phenomena (Girandola, 2005; Joule\&Beauvois, 1998; Kiesler, 1971).According to Kiesler, people who act become committed, almost despitethemselves, to their action hence impacting people's attitudes and behavior.As far as attitudes are concerned, committing oneself to a counterattitudinalaction (i.e. one that goes against one's attitudes) results in achange of attitude or rationalization (a better adjustment of attitude toaction). Whereas commitment to an action in line with one's attitudesleads to a consolidation of the attitude. A better resistance to subsequentinfluence attempts may be observed in that case. For example, signing apetition in favor of a cause that one holds close to heart enables to betterresist attacks targeting this cause.Concerning behavior, committing oneself to a decisional action leadsthe person making this decision to stick to it (freezing effect, low-balleffect). Committing first to an innocuous action increases the likelihood

of complying to subsequent more demanding requests as long as thecourse of action remains consistent (teasing effect and foot-in-the-door).However, this type of impact on attitudes and behavior can be observedonly as long as the first action (preparatory action) was carried out inspecific commitment conditions. Therefore, the same action can be more or less binding, and can even be seen as nonbinding. Studies have shownthat the stronger the commitment the bigger the effects.Strong commitment can be obtained by playing on several factors,among which:

1 The context of freedom in which the action was carried out: an actioncarried out in a context of freedom is more binding than when carriedout in a context of constraint. 
2 The public nature of the action: an action carried out in public is morebinding than when anonymity is guaranteed.

3 The explicit nature of the action: an explicit action is more bindingthan an ambiguous one.

4 The irrevocability of the action: an irrevocable action is more bindingthan one that is not.

5 The repetition of the action: an action that is repeated is more binding than an action carried out once.

6 The consequences of the action: an action will be more binding if it isfilled with consequences.

7 The cost of the action: an action will be more binding if it is costly inmoney, time, energy, etc.

8 The reasons for the action: an action is the more so binding that it cannotbe attributed to external reasons (e.g. promises of a reward, threats ofpunishment) but can be imputed to internal reasons (e.g. personalvalues, personality traits). In other words, external reasons unbind whileinternal reasons bind.

According to the circumstances, subjects will feel more or less bound bythe act they were induced into doing. We can therefore understand whyKiesler chose to define commitment as the link between people and theiractions. It is quite easy to grasp, for instance, that the link will be strongerwhen the person acts in a context of freedom rather than in one ofconstraint. But one should be careful: it is not the subjects per se whocommit to their actions according to their ideas. In such a case, we wouldindeed be authorized to talk about 'internal' commitment. We are referringhere to 'external' commitment because the fact of committing oneself(or not) to one's actions derives from circumstances with their objectivecharacteristics. Kiesler's definition is somewhat ambiguous on this mainpoint. We would therefore prefer to use the following definitions that betterunderscore the external - and solely external - nature of a commitment:'In a given situation, a commitment corresponds to the conditions inwhich an action can only be attributed to the person who carried it out,'or 'a commitment corresponds to the conditions in which an action wascarried out and enabling an attributor (either an eyewitness, the personhim or herself, or any person aware of what happened) to match thisaction to the person who carried it out' ( Joule \&Beauvois, 1998, 60).

\section{The Path to Binding Communication}

Throughout this article, we have shown that good ideas are not enoughto make people change their ways. But we have also shown that it doesn'ttake much - namely, a few well-designed preparatory actions - to inducepeople into moving from ideas to actions. For this reason, we deem thatcommunication campaigns could be more effective if the preparatoryactions to be obtained by the target were not neglected. This is quite achallenge as it entails imparting to the target a status of player rather thanmerely receiver. From a practical point of view, the target's player statuswill lead him or her to carry out binding preparatory actions 'inconsistent'with the subsequent influences that we want him or her to resist (incitementto drug use or racial hatred, for example). To the contrary, thepreparatory actions will actually lead the target to carry out actions consistentwith the subsequent desirable influences (educational or awarenessmessages, for example).In any given program of communication, the main questions to betreated remain of course: 'What type of information should be conveyed?' What are the best arguments to offer?' 'What are the most appropriatechannels, tools, supports, and medias?' etc., but more importantly, 'Whichpreparatory actions must I obtain from those I want to rally?' This lastquestion imparts a status of player to the target, thus, setting apart a 'binding'communication approach from a more 'traditional' approach (see, inparticular, Joule et al., 2004).To illustrate this point, we will describe a 'binding' communicationaction carried out in 11 schools in the south of France within the frameworkof the 
European project ALTENER. The aim of this project, whichtook place during the 2002-2003 school year, was to encourage 9- and10-year-old children and their parents to develop environmentally friendlybehavior. Seven hundred families along with 28 teachers were involved.During the school year, the teachers did more than just inform (lessons, background information, etc.) and convince students of the importanceof protecting the environment and of conserving energy, they made theirstudents actually carry out preparatory actions (about once a month). Thefirst action was to determine what were the environmentally friendly andenergy saving 'good practices' and the 'notso-good practices' in theirschool. In a second action, the children were asked to do the same thingat home by taking note of family habits that could be changed withoutcausing much inconvenience. The third action involved parents (firstpreparatory action for the parents) who were asked to help their child fillin a questionnaire about energy savings at home. In the fourth preparatoryaction (second for the parents), the child put a sticker about the preservationof the environment on the family fridge, etc.

Obviously, the results of each preparatory action were shared withothers in school. The children talked about what they had noticed atschool and shared their findings about their own homes. The children read and analyzed together the questionnaires filled in with their families.

Each child spoke about family reactions to the sticker on the fridge.At the end of the school year, each student was encouraged by theteacher to make a public and written commitment to change at least oneof his or her habits, for example, to take a shower instead of a bath or toturn off the tap when brushing their teeth. Each child was to inform hisor her parents of this commitment also encouraging them to make aspecific commitment of their own: to leave the car at home when travelingshort distances or to replace ordinary bulbs by low wattage bulbs. Thesecommitments were made more official through the signing of two forms:the child signed one in the classroom, and the family signed one at home. The conclusions are very positive. The vast majority of children and parents (100\% in some classes), made a written pledge to carry out specificactions likely to decrease energy consumption. Several studies have shownthat written commitments are more likely to be followed through (see, inparticular, for environmental issues: Katzev\& Wang, 1994; Pallack, Cook, \& Sullivan, 1980; Wang \&Katzev, 1990, for a summary of the long-term effects of commitment, see Girandola\&Roussiau, 2003). It's hard to imaginehow parents, who, at the request of their son or daughter, have made awritten commitment to replace ordinary bulbs by low wattage bulbs could not do it. Parents generally want to set a good example and do not want their child to perceive them as untrustworthy. But there is more. Thedynamic set in motion by this approach has also led to improvements insome of the schools such as switching from ordinary bulbs to low wattagebulbs or setting up paper recycling bins. Finally, some students wrote tothe local authorities to ask that timers be installed for the lights in schoolcorridors. The above action represents a perfect example of a binding communicationapproach. It is not just about presenting targets with informationand arguments. Efforts are put into encouraging targets (i) to carry outpreparatory actions and (ii) to make specific commitments. In promotingthis approach, our aim is to support the development of studies seekingto integrate, on the one hand, research on the role of commitment andfree will compliance with, and on the other hand, research dealing withcommunication in general and those with a more specific focus on persuasivecommunication. This direction seems quite promising as it offersexciting new paths for research having important theoretical and practicalimplications.

\section{Short Biography}

Robert-Vincent Joule is Professor of Social Psychology at Université deProvence (France). He is Head of the Laboratoire de PsychologieSociale. His research interests are in cognitive dissonance and social influenceprocedures (free will compliance). He is the author (with Jean-Léon Beauvois) of $A$ Radical Dissonance Theory (London and Bristol: Taylor \&Francis, 1996). His most recent research concerns communication andmore specifically 'binding communication'. His best-known works are Lasoumissionlibrementconsentie(Paris: Presses Universitaires de France, 1998) (written with Beauvois) and also the Petit traité de manipulation à l'usage deshonnêtes gens (Grenoble: Presses Universitaires de Grenoble, 2002), a best seller that has sold 200,000 copies in France and has been 
translated inseveral languages (also written with Beauvois). He was awarded the Prix de la diffusion scientifique at the Festival des Sciences et des Technologies en 2002 (President of the Jury: Yves Coppens).

Fabien GirandolaisProfessor of Social Psychologyat Université deBourgogne (Dijon, France) and assistant director of the Laboratoire deSocio-Psychologie et Management du Sport. His research focuses on the theory of commitment, cognitive dissonance, social influence procedures(free will compliance), persuasion and resistance to persuasion, decisionmaking. His most recent research interest is on 'binding communication'more specifically in the domain of environment, health. He is the author of Psychologie de la persuasion et de l'engagement (Presses Universitaires deFrancheComté, 2003).Françoise Bernard isProfessor of Information Sciences and Communicationat Université de Provence (France). Sheis Head of the Centre deRecherche sur les Pratiques de Communication et de Médiation. ShewasPresident of the Société Française des Sciences de I'Information et de laCommunication from 2002 to 2006, and iscurrentlyitsHonoraryChair. She has worked on communication, change, and innovation within organizations. Her most recent research focuses on 'binding communication' and is conducted in partnership with Robert-Vincent Joule. She examines, among other things, the relationship between communicationand action in the domain of the environment.

\section{Endnote}

* Correspondenceaddress: Laboratoire de Psychologie Sociale, Université de Provence, 29 avenueR. Schuman, 13621 Aix-en-Provence Cedex 1, France. Email: joule-rv@up.univ-aix.fr.

\section{References}

Albarracin, D., Durantini, M. R., \& Earl, A. (2006). Empirical and theoretical conclusions ofan analysis of outcomes of HIV-Prevention interventions.Current Directions in PsychologicalScience, 15, 73-78.

Albarracin, D., Gillette, J. C., Earl, A. N., Glasman, L. R., \&Durantini, M. R. (2005). A testof major assumptions about behavior change: A comprehensive look at the effects of passiveand active HIVprevention interventions since the beginning of the epidemic. PsychologicalBulletin, 131, 856-897.

Burger, J. M. (1999). The foot-in-the-door compliance procedure: A multiple-process analysisand review. Personality and Social Psychology Review, 3, 303-325.

Cialdini, R. B. (2000). Influence: Science and Practice. Boston, MA: Allyn\& Bacon.

Cialdini, R. B., Cacioppo, J. T., Basset, R., \& Miller, J. A. (1978). Low-ball procedure forproducing compliance: Commitment then cost. Journal of Personality and Social Psychology, 36,463-476.

Dukes, R., Ullman, J., \& Stein, J. (1996).Three-year follow-up of Drug Abuse ResistanceEducation (DARE).Evaluation Review, 20, 49-66.

Ennett, S., Tobler, N., Ringwalt, C., \&Flewelling, R. (1994). How effective is drug abuseresistance education? A meta-analysis of project DARE outcome evaluations.American Journalof Public Health, 84, 1394-1401.

Freedman, J. L., \& Fraser, S. C. (1966). Compliance without pressure: The foot-in-the-door technique. Journal of Personality and Social Psychology, 4, 195-202.

Girandola, F. (2003). Psychologie de la persuasion et de l'engagement. Besançon, France: PressesUniversitaires de Franche-Comté. 
Girandola, F. (2005). Action and commitmenttheory. In V. Alexandre\& W. Gasparski (Eds.), French and Other Perspectives in Praxeology (Vol. 12, pp. 117-130). New Brunswick andLondon: Transaction Publishers.

Girandola, F., \&Roussiau, N. (2003). L'engagement comme source de modification à longterme. Les Cahiers Internationaux de Psychologie Sociale, 57, 83-101.

Guéguen, N. (2002a). Psychologie de la Manipulation et de la Soumission. Paris: Dunod.

Guéguen, N. (2002b). King of touch, gender and compliance to a request: A pilot study. StudiaPsychologica, 44, 167-172.

Guéguen, N. (2002c). Nonverbal encouragement of participation in a course: The effect oftouch. Social Psychology of Education, 7, 89-98.

Guéguen, N., \&Pascual, A. (2000). Evocation of freedom and compliance: The 'but you arefree of ...'technique. Current Research in Social Psychology, 5, 264-270.

Guéguen, N., LeGouvello, J., Pascual, A., Morineau, T., \& Jacob, X. (2002). Request solicitation and semantic evocation of freedom: An evaluation in a computer-mediated communication context. Perceptual and Motor Skills, 95, 208-212.

Joule, R. V., \&Beauvois, J. L. (1998). La Soumission Librement Consentie. Paris: Presses Universitairesde France.

Joule, R. V., \&Beauvois, J. L. (2002). Petit Traité de Manipulation à l'usage des Honnêtes Gens.Grenoble, France: Presses Universitaires de Grenoble.

Joule, R. V., Gouilloux, F., \& Weber, F. (1989). The lure: A new compliance procedure. Journalof Social Psychology, 129, 741-749.

Joule, R. V., Py, J., \& Bernard, F. (2004). Qui dit quoi, à qui, en lui faisant faire quoi? Versune communication engageante. In M. Bromberg \& A. Trognon (Eds.), Psychologie Sociale etCommunication (pp. 205-218). Paris: Dunod.

Katzev, R., \& Wang, T. (1994). Can commitment change behavior? A case study of environmentalactions.Journal of Social Behavior and Personality, 9, 13-26.

Kiesler, C. A. (1971). The Psychology of Commitment. Experiments Liking Behavior to Belief. NewYork: Academic Press.

Kleinke, C. (1973). Compliance to requests made by gazing and touching in field settings.Journal of Experimental Social Psychology, 13, 218-223.

Lewin, K. (1947). Group decision and social change.In T. Newcomb \& E. Hartley (Eds.),Readings in Social Psychology. New York: Holt.

Moriarty, T. (1975). Crime, commitment, and the responsive bystander: Two field experiments.Journal of Personality and Social Psychology, 31, 370-376.

Pallack, M., Cook, D., \& Sullivan, J. (1980).Commitment and energy conservation.AppliedSocial Psychology Annual, 1, 235-253. 
Peterson, A. V., Kealey, K. A., Mann, S. L., Marek, P. M., \&Sarason, I. G. (2000). HutchinsonSmoking Prevention Project: Long-term randomized trial in school-based tobacco use prevention- results on smoking. Journal of the National Cancer Institute, 92, 1979-1991.

Steward, L., \&Lupfer, M. (1987).Touching as teaching: The effect of touch on students'perceptions and performance.Journal of Applied Social Psychology, 17, 800- 809.

Wang, T. H., \&Katzev, R. D. (1990). Group commitment and resource conservation: two fieldexperiments on promoting recycling. Journal of Applied Social Psychology, 20, 265-275. 